There is a limited scope for improvement of wheat production when well-designed research efforts are made. The costs of the necessary infrastructural investments have to be weighted against the benefits of improved wheat production at the regional level.

\title{
References
}

Hurd, E. A., 1981. Status of research and production, Zambia. In: J. A. Toogood (Ed.), Proceedings Wheat Workshop (Mount Makulu Research Station, Chilanga) 19-20.

James, W. C., 1971. An illustrated series of assessment keys for plant diseases, their preparation and usage. Canadian Plant Disease Surveys 51: 39-54.

Robinson, R. A., 1976. Plant pathosystems. Advanced series in agricultural sciences 3. Springer. Berlin. $184 \mathrm{pp}$.

Robinson, R. A. \& L. Chiarappa, 1977. The International Programme on Horizontal Resistance. FAO Plant Protection Bulletin 25: 197-200.

Van der Plank, J. E., 1968. Disease resistance in plants. Academic Press, New York/San Francisco/London, $206 \mathrm{pp}$.

This synopsis is based on a doctoral thesis entitled 'Improvement of wheat in Zambia using incomplete resistance against rusts', Agricultural University, Wageningen, 1983. ix +156 pp., 28 figs., 54 tables, 230 refs. English, Dutch summary.

Available as paper copy (order R003P, $f 30$ including postage) or microfiches (order R003M, $f 17.50$ including postage) at: NARD, c/o Pudoc, P.O. Box 4, $6700 \mathrm{AA}$ Wageningen, Netherlands (telex 45015 blhwg nl).

\section{The African catfish - A new species for aquaculture}

H. Hogendoorn (Dept. of Fish Culture and Inland Fisheries, Agricultural University, Wageningen, Netherlands. Present address: Organization for Improvement of Inland Fisheries, P.O. Box 433, 3430 AK Nieuwegein, Netherlands)

Accepted: 12 January 1984

\begin{abstract}
Trials in fish ponds in Cameroon and in laboratory tanks in the Netherlands suggest that African catfish (Clarias lazera) is highly suitable for aquaculture and can replace Nile tilapia (Sarotherodon niloticus) in African fish farms.
\end{abstract}

Key-words: Clarias lazera, African catfish, fish farming, fish culture, reproduction, feed efficiency, energy metabolism. 
Introduction. Fish culture was introduced to Africa between 1946 and 1960. In $1959 / 60$, almost 300000 ponds were in operation in about 20 African countries (Meschkat, 1967). After 1960, interest in aquaculture declined and most ponds were abandoned (Huet, 1972). The fish farmers became discouraged when they harvested too many small tilapia from over-populated ponds. Despite joint support from African governments and international development assistance, tilapia culture could not be adequately organized (Miller, 1975; Hepher \& Pruginin, 1982).

The 1966 World Symposium on Warm-water Pond Fish Culture recommended a search for other African fish more suitable for culture (Lemasson \& Bard, 1968). Local fish were studied (Micha, 1973) and the labyrinthic catfish Clarias lazera attracted attention (De Kimpe \& Micha, 1974).

Materials and methods. In small ponds at the national Fish Culture Centre in Foumban, Cameroon, propagation procedures, growth and production were studied. Results were compared with those for the Nile tilapia (Sarotherodon niloticus). The most promising procedures were further checked in laboratory tanks in the Netherlands. Limits of the growth of $C$. lazera in intensive tanks were assessed in a tri-facorial trial with body weight, temperature and feeding level as variables. A mathematical model was developed to describe the relation between these factors and to present a guide for recommended feeding levels. The relation of body weight with feed and energy exchange was studied with open-circuit balance respirometers.

Results. The scarce literature on the reproductive biology of $C$. lazera showed that it is a communal spawner, mostly maturing in the rainy season. Field tests simulating natural spawning conditions or using hormones to induce spawning were not reliable for planned fingerling production.

With artificial reproduction, however, ovulation could be induced with acetonedried carp pituitary and the sexual products were obtained by stripping the females and dissecting the testes of the males. The eggs could then be artificially fertilized, incubated and hatched to provide a reliable supply of fry.

During a first phase of rearing the fry to fingerlings, $C$. lazera requires natural, preferably live, feed. After one or two weeks, they can be switched to a compound dry feed. Under good conditions, the young catfish grow to well over $10 \mathrm{~g}$ at two months of age.

When the fingerlings were cultured to marketable size in ponds, yield was 2.5 as much as for tilapia. With a low-grade feed composed of local agricultural by-products, the individual fish weight decreased with increasing stocking density, suggesting that the fish depended on the natural productivity of the pond to complete their diet. Optimum stocking density, therefore, must be decided on the basis of consumer preferences for fish size and of the economics of the process.

Intensive culture of $C$. lazera in tanks on a complete pelleted feed resulted in rapid growth and good feed conversion (0.6-1.0). The calorimetric study showed that about $70 \%$ of the feed is metabolized. About $80 \%$ of the metabolized energy was utilized for growth, and very little was required for maintenance.

Water temperature influenced growth and feed utilization in three ways: at an 


\section{H. HOGENDOORN}

Table 1. Recommended feeding levels (\% body weight day-1) and (in parenthesis) corresponding estimated growth rates (\% body weight day-1) for $C$. lazera from 1 to $200 \mathrm{~g}$ between 20 and $30^{\circ} \mathrm{C}$.

\begin{tabular}{lllllll}
\hline $\begin{array}{l}\text { Temp. } \\
\left({ }^{\circ} \mathrm{C}\right)\end{array}$ & \multicolumn{6}{l}{ Body weight $(\mathrm{g})$} \\
\cline { 2 - 6 } & 1 & 5 & 25 & 50 & 100 & 200 \\
20 & $2.9(3.1)$ & $1.9(2.6)$ & $1.2(1.5)$ & $1.0(1.1)$ & $0.9(0.6)$ & \\
21 & $3.6(4.2)$ & $2.5(3.6)$ & $1.7(2.3)$ & $1.4(1.7)$ & $1.2(1.0)$ & $1.0(0.4)$ \\
22 & $4.4(5.3)$ & $3.1(4.6)$ & $2.2(3.0)$ & $1.9(2.3)$ & $1.6(1.4)$ & $1.4(0.6)$ \\
23 & $5.1(6.3)$ & $3.7(5.6)$ & $2.6(3.8)$ & $2.3(2.9)$ & $2.0(1.9)$ & $1.7(0.9)$ \\
24 & $5.8(7.2)$ & $4.2(6.5)$ & $3.1(4.4)$ & $2.7(3.4)$ & $2.3(2.2)$ & $2.0(1.1)$ \\
25 & $6.5(8.0)$ & $4.7(7.3)$ & $3.4(5.0)$ & $3.0(3.8)$ & $2.6(2.6)$ & $2.3(1.2)$ \\
26 & $7.0(8.7)$ & $5.1(7.9)$ & $3.7(5.4)$ & $3.3(4.2)$ & $2.8(2.8)$ & $2.5(1.4)$ \\
27 & $7.4(9.2)$ & $5.4(8.3)$ & $3.9(5.7)$ & $3.4(4.4)$ & $3.0(2.9)$ & $2.6(1.4)$ \\
28 & $7.7(9.6)$ & $5.6(8.5)$ & $4.0(5.8)$ & $3.5(4.4)$ & $3.0(2.9)$ & $2.6(1.4)$ \\
29 & $7.9(9.7)$ & $5.6(8.6)$ & $4.0(5.7)$ & $3.5(4.3)$ & $3.0(2.8)$ & $2.6(1.3)$ \\
30 & $8.0(9.7)$ & $5.6(8.5)$ & $3.9(5.6)$ & $3.4(4.2)$ & $2.9(2.7)$ & $2.5(1.2)$ \\
\hline
\end{tabular}

optimum temperature, growth rate reached a maximum; the optimum varied with body size, $27.5-32.5^{\circ} \mathrm{C}$ for small fish and $25.0-27.5^{\circ} \mathrm{C}$ for larger fish; feed efficiency also had a temperature optimum, because the capacity for feed utilization increased faster with temperature than did maintenance requirements.

Table 1 presents recommended feeding levels for $C$. lazera from 1 to $200 \mathrm{~g}$ between 20 and $30^{\circ} \mathrm{C}$.

Discussion. By contrast to natural or induced propagation of C. lazera in ponds, artificial reproduction and controlled rearing of fry provided a reliable supply of fingerlings. Since fresh Clarias pituitary can also be used to induce ovulation of the eggs and since eggs can be incubated in stagnant water, artificial reproduction can easily be applied in Africa. If a nursery pond is used to rear fry, ample zooplankton must be available and predatory animals must be kept under control.

The suitability of African catfish for aquaculture was confirmed by their growth from fingerlings to marketable size showing that (1) they can grow fast and efficiently in densely stocked ponds, (2) they are hardy and tolerate water of poor quality.

The catfish is a promising alternative to tilapia in subsistence fish farming in developing countries and in intensive aquaculture both in developing and industrialized countries. For extension of Clarias culture, the main limiting factors in industrialized countries would be cheap warm water and acceptance by the consumer. For developing countries, the limitation is development programming.

\section{References}

De Kimpe, P. \& J. C. Micha, 1974. First guidelines for the culture of Clarias lazera in Central Africa. Aquaculture 4: 227-248.

Hepher, B. \& Y. Pruginin, 1982. Tilapia culture in ponds under controlled conditions. In: R. S. V. Pullin \& R. H. Lowe-McConnel (Eds.), The biology and culture of tilapias. ICLARM Conference Proceedings 7: 85-103. Manilla, Philippines. 
Huet, M., 1972. Textbook of fish culture. Fishing News (Books) Ltd., 436 pp.

Lemasson, J. \& J. Bard, 1968. Nouveaux poissons et nouveaux systèmes pour la pisciculture en Afrique. In: T. V. R. Pillay (Ed.), Proceedings World Symposium on Warm-water Pond Fish Culture. FAO Fish Report 44 (5) 182-195.

Meschkat, A., 1967. The status of warm-water pond fish culture in Africa. In: T. V. R. Pillay (Ed.), Proceedings World Symposium on Warm-water Pond Fish Culture. FAO Fish Report 44 (2) 88-122.

Micha, J.-C., 1973. Etude des populations piscicoles de l'Ubangui et tentatives de sélection et d'adaptation de quelques espèces à l'étang de pisciculture. CFTF, Paris, 110 pp.

Miller, J. W., 1975. Review and evaluation of rural fish culture extension in the Central African Republic. UNDP/FAO-CAF/72/002.

This synopsis is based on a doctoral thesis, Agricultural University, Wageningen, 1983. Major part published as papers in Aquaculture (Elsevier, Amsterdam). 140 pp., 21 figs, 28 tables, refs. English, Dutch summary.

Available as paper copy (order R004P, $f 30$ including postage) or microfiches (order R004M, f 17,50 including postage) at: NARD, clo Pudoc, P.O. Box 4, 6700 AA Wageningen, Netherlands (telex 45015 blhwg $\mathrm{hl}$ ).

\title{
The influence of vegetation on acoustic properties of soils. Measurements of acoustic impedances of outdoor surfaces with application to traffic noise reduction
}

L. A. M. van der Heijden (Department of Botany I, Catholic University, Toernooiveld, 6525 ED Nijmegen, Netherlands)

Accepted: 28 December 1983

\begin{abstract}
The acoustic impedance and specific air flow resistance of 23 outdoor surfaces were measured. Vegetations have a large influence on the sound absorption characteristics of these surfaces. However, this has almost no consequences for the A-weighted total sound pressure level of traffic noise.
\end{abstract}

Key-words: soil acoustics, outdoor sound propagation, acoustic impedance, specific air flow resistance, traffic noise.

Introduction. The influence of vegetation on the propagation of outdoor sound is subject to a continuing controversy. Especially the advocates of the 'green solution' 